\title{
Hodgkin lymphoma in a young child contributing to a diagnosis of ataxia telangiectasia: review of the literature
}

\author{
Jennifer M. Hummel • Erik C. Thorland • Megan S. Lim
}

Received: 19 February 2010 /Accepted: 14 May 2010 /Published online: 15 June 2010

(C) Springer-Verlag 2010

\begin{abstract}
Ataxia telangiectasia (A-T) is a rare genetic disorder characterized by progressive cerebellar ataxia, oculocutaneous telangiectasias, immunodeficiency, chromosomal instability, and radiation sensitivity (Peterson et al. Lancet 283:1189-1193, 1964; Boder and Sedgwick Pediatrics 21:526-554, 1958; Taylor et al. Nature 258:427$429,1975)$. Compared to the general population, patients with primary immunodeficiencies such as A-T have an increased rate of malignancy and an earlier age at presentation (Loeb et al. J Pediatr Hematol/Oncol 22:464467, 2000; Taylor et al. Blood 87:423-438, 1996). We report the clinical, histopathologic, and molecular features of a 6-year-old child who presented with EBV-positive Hodgkin lymphoma (HL), which led to the diagnosis of ataxia telangiectasia. The diagnosis of $\mathrm{HL}$ at this unusually young age prompted further clinical, immunologic and cytogenetic evaluations, all of which supported a diagnosis of A-T. Because A-T patients are exquisitely sensitive to radiation, the patient was put on a modified chemotherapeutic regimen; however, 14 months later, he experienced a relapse and passed away by age 9 . Classical HL is relatively rare among A-T patients, and this is the first documented case of an EBER-1 positive Hodgkin lymphoma in an ataxia telangiectasia patient. A review of the literature examining cases of $\mathrm{HL}$ in A-T is provided.
\end{abstract}

\footnotetext{
J. M. Hummel • M. S. Lim ( $₫)$

Department of Pathology, University of Michigan,

5242 Medical Science I, 1301 Catherine St,

Ann Arbor, MI 48109-5602, USA

e-mail: meganlim@umich.edu

E. C. Thorland

Department of Laboratory Medicine and Pathology, Mayo Clinic,

Rochester, MN, USA
}

Keywords Ataxia telangiectasia $\cdot$ Diagnosis . Hodgkin lymphoma

\section{Introduction}

Ataxia telangiectasia (A-T) is caused by mutations in the DNA damage response gene ataxia telangiectasia mutated (ATM) [1] located on chromosome 11 [2]. In response to the introduction of double-stranded DNA breaks, ATM normally halts the cell cycle to allow time for repair. ATM is also involved in mitogenic signal transduction, apoptosis, and interacts with numerous regulatory substrates including p53, BRCA1, CHK2, and Nbs1 [3]. A-T has a birth frequency of approximately one in $300,000[4,5]$ and up to $1 \%$ of the population are heterozygous carriers of mutated ATM genes [6]. Due to the pleiotropic effects of ATM, A-T patients may display clinical heterogeneity; however, the first signs of ataxia usually manifest by age 2 [7-9]. The characteristic telangiectasias may not appear until age 6 or later, and by their second decade, most patients require a wheelchair for mobility [7-9]. The degree of immunodeficiency is variable, with defects in humoral immunity, cellmediated immunity or both [10]. Classically, the most common findings include decreased serum $\operatorname{IgA}, \operatorname{IgG} 2$ and IgG4, diminished numbers of naïve CD4 $\mathrm{T}$ cells, and thymic hypoplasia [10]. Other laboratory features typical of A-T include elevated alpha fetoprotein [11], sensitivity to ionizing radiation and chromosomal breakage [12]. Up to $10 \%$ of the T-lymphocytes in A-T patients have translocations and inversions, mainly involving chromosomes 7 and 14, and some of these breakpoints are found within the T-cell antigen receptor genes on chromosome 7 [11]. A-T patients have an increased risk of developing cancer, and 
Hodgkin lymphoma accounts for $10 \%$ of all malignancies seen in these patients [13]. A-T patients present with Hodgkin lymphoma at a younger age than the general pediatric population, and usually at an advanced stage of disease [14]. The diagnosis of malignancy may precede the diagnosis of A-T or follow it.

\section{Materials and methods}

Histologic and immunophenotypic studies

Tissue from the bone marrow and lymph node biopsies was formalin fixed, paraffin embedded, and sectioned into hematoxylin and eosin-stained slides. Immunohistochemical studies were performed using the biotin-free Ultraview DAB detection system and an automated immunostainer (Ventana-Biotech, Tucson, AZ, USA). The following immunostains were performed using the following antibodies: anti-CD3 (Ventana, Tucson, AZ, USA), anti-CD15 (Becton Dickinson, San Jose, CA, USA), anti-CD20 (Ventana), anti-CD30 (Dako), fascin (Dako), and Pax 5 (clone 24 B-D Biosciences Lexington, KY, 1/50 dilution). Gomori methenaimine silver stain was used to identify yeast and fungal organisms in tissue. The Fite stain modification of the Ziehl-Neelsen stain was used to identify acid-fast organisms. Appropriate positive and negative controls were used for all immunohistochemical studies.

\section{Molecular studies}

In situ hybridization An automated in situ hybridization instrument was used to perform the in situ hybridization for Epstein-Barr virus (EBV). EBER-1, an EBV-encoded digoxigenin-labeled RNA riboprobe, was diluted in a 50\% formamide-containing buffer and applied to the tissue sections and to appropriate positive and negative controls. An antisense riboprobe directed against a small nuclear ribonucleoprotein was used to confirm satisfactory RNA integrity of the tissue sections.

\section{Results}

\section{Clinical history}

The patient is a 6-year-old boy with a history of developmental delay and "clumsiness" who presented to the emergency room with abdominal pain, fever, and fatigue. On physical examination, he had hepatomegaly. Laboratory studies were notable for leukopenia (white blood cells $1.8 \mathrm{~K} / \mathrm{mm}^{3}$ ), anemia (hemoglobin $8.6 \mathrm{~g} / \mathrm{dl}$ ), elevated liver indices (115 IU/L, AST $74 \mathrm{IU} / \mathrm{L}$, alkaline phostphatase $988 \mathrm{IU} / \mathrm{L}$, total bilirubin $2.7 \mathrm{mg} / \mathrm{dl}$ ), and a markedly elevated alpha fetoprotein $(109.6 \mathrm{ng} / \mathrm{ml})$. EBV serology revealed that the patient was positive for viral capsid antigen (VCA) IgG, but was negative for early antigen (EA), and Epstein-Barr nuclear antigen (EBNA). Acute lymphoblastic leukemia, viral hepatitis, hepatocellular carcinoma, and germ cell tumor were all considered in the differential diagnosis. The bone marrow biopsy revealed granulomas; however, an infectious etiology was ruled out. A computed tomography scan detected enlarged mediastinal, periaortic, and supraclavicular lymph nodes. While further bone marrow immunohistochemistry was pending, a subsequent lymph node biopsy with immunohistochemical analysis led to a diagnosis of stage IVB Hodgkin lymphoma, nodular sclerosis type. The diagnosis of Hodgkin lymphoma (HL) at this unusually young age prompted further clinical and laboratory work up which revealed oculomotor apraxia and subtle truncal ataxia as well as hypogammaglobulinemia (IgM $38 \mathrm{mg} / \mathrm{dl}$, IgG2 $47 \mathrm{mg} / \mathrm{dl}$ ). Cytogenetic evaluation of the blood showed results consistent with ataxia telangiectasia (Fig. 3). Because A-T patients are exquisitely sensitive to radiation, the patient was put on a modified chemotherapeutic regimen developed at St. Jude's Hospital, which resulted in remission for 14 months; however, he relapsed and passed away by age 9 .

\section{Bone marrow}

Hematoxylin and eosin-stained sections from the bone marrow revealed non-necrotizing granulomas (Fig. 1a), eosinophilia, and rare large atypical cells with prominent eosinophilic nucleoli, suspicious for Reed-Sternberg cells (Fig. 1b). Fite and GMS stains of the bone marrow were negative for acid fast bacilli and fungal elements. Immunohistochemical staining showed that the large atypical cells in the bone marrow expressed CD30 (Fig. 1c) and weak PAX5, they were negative for CD20 and CD3. No definite staining for CD15 was observed, and a fascin stain was noncontributory.

Lymph node

A biopsy of the supraclavicular lymph node revealed architecture that was effaced by a mixed infiltrate of small lymphocytes, eosinophils, and scattered large abnormal cells; some sclerosis was present (Fig. 2a). The abnormal cells had large prominent hyperchromatic nucleoli (Fig. 2b), consistent with lacunar Reed-Sternberg variants. Rare classical Reed-Sternberg cells and mummified cells were also present (Fig. 2c). Immunohistochemical staining 


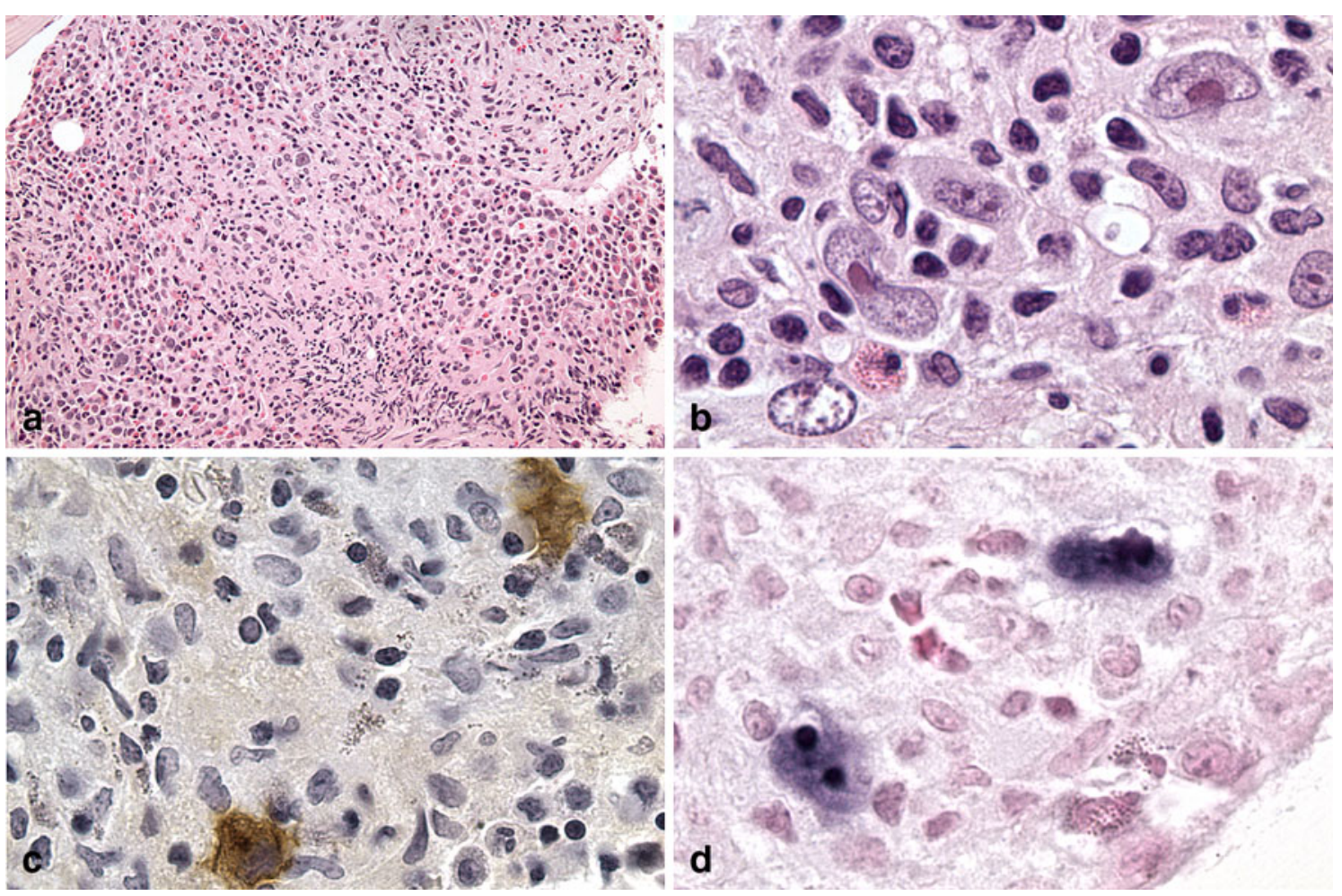

Fig. 1 Morphologic, immunohistochemical, and molecular features of the bone marrow involvement by classical Hodgkin lymphoma. a Increased eosinophils and non-necrotizing granulomas, with rare

of the lymph node biopsy confirmed that the neoplastic cells expressed CD30 (Fig. 2d) and were negative for CD20 and CD3. A subset of Reed-Sternberg cells expressed CD15 in a Golgi distribution (Fig. 2e). This immunohistochemical pattern further supported the morphologic impression of classical Hodgkin lymphoma, nodular sclerosis type.

\section{Molecular studies}

Since Epstein-Barr virus is associated with lymphomas in immunodeficiency states, in situ hybridization for EpsteinBarr virus ribonucleic acid was performed and demonstrated numerous positive Reed-Sternberg cells in the lymph node (Fig. 2f) and occasional positive cells in the bone marrow (Fig. 1d).

\section{Cytogenetic studies}

Initial cytogenetic evaluations of the blood and lymph node were non-contributory due to poor growth in culture and low cell yield, respectively. Repeat cytogenetic analysis of the blood showed $10 \%$ of cells with chromosomal breakage, including three metaphases with $7 ; 7$ translocations, a 14;14 translocation, a 1;8 translocation and a dicentric chromosome (Fig. 3). The excess breakage in associated large, atypical cells. b Mononuclear Reed-Sternberg (RS) cells with prominent eosinophilic nucleoli. c CD30+ mononuclear RS cells. d Rare EBER-1 positive RS cells

conjunction with the $7 ; 7$ and $14 ; 14$ translocations was characteristic of ataxia telangiectasia.

\section{Discussion}

Hematologic malignancy in A-T

A-T patients have an increased risk of developing cancer, at approximately 100 times the age-specific population rate [5]. Of the A-T patients, $10-30 \%$ develop a malignancy and nearly $75 \%$ of these malignancies are lymphomas or leukemias [15]. Much of the data on the incidence of cancer subtypes in primary immunodeficiency patients comes from the National Immunodeficiency Cancer Registry (ICR) established in 1973 [16].

A-T patients comprise approximately one third of the ICR; $21.3 \%$ of the total malignancies reported in ataxia telangiectasia were leukemias, $46 \%$ were lymphomas, and $10.7 \%$ were classified as Hodgkin lymphoma [13].

Most cases of lymphoma in A-T occur in children and are diagnosed at a younger age than in the general pediatric population [11, 17]. Conversely, most cases of acute lymphoblastic leukemia in A-T present at an older age (average 9 years) [18]. Only one case of acute myeloid leukemia in an A-T patient has been reported in the 


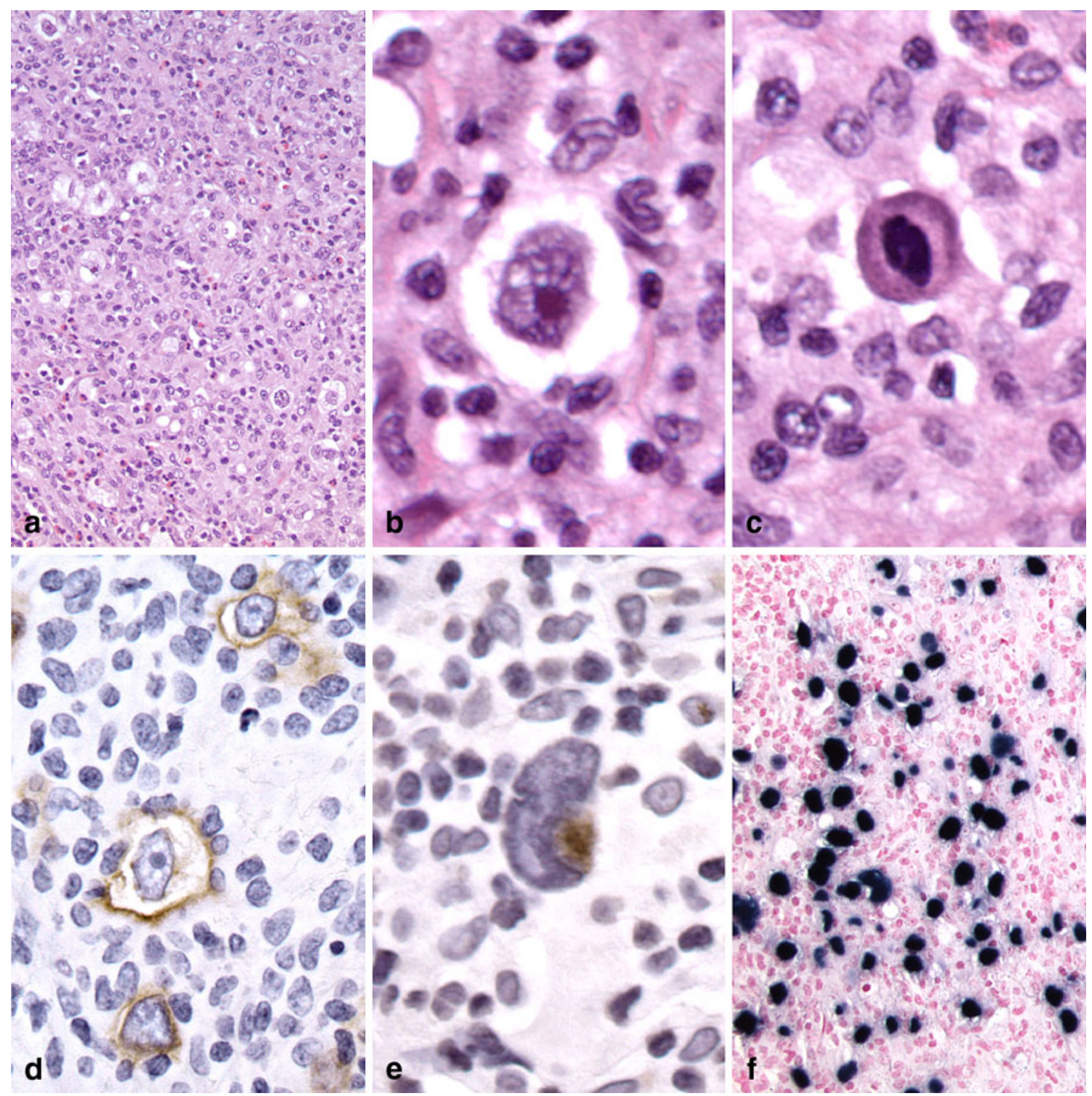

Fig. 2 Morphologic, immunohistochemical and molecular features of the supraclavicular lymph node involvement by classical Hodgkin lymphoma, nodular sclerosis type. a Effaced nodal architecture with background sclerosis and a mixed cellular infiltrate consisting of

literature to date [19]. Unlike the incidence of hematologic malignancies seen in other types of primary immunodeficiencies, there is a 6:1 ratio of T-cell to B-cell neoplasms in A-T, although the incidence of B-cell neoplasms is still increased compared to that of the general population [20]. In a UK case series examining leukemia and lymphoma subtypes in A-T patients, three of the 17 patients had B-cell tumors, at least 11 had T-cell tumors, and only patient had HL [20]. Only three of the patients were adults (ages 2343 years); the remaining 14 were children aged 2-15, (median age 6) [20]. Young adults with A-T have an increased rate of T-PLL compared to children with A-T [20]. Of the non-Hodgkin B-cell lymphomas, diffuse large eosinophils, lymphocytes and lacunar and classic Reed-Sternberg cells. b Lacunar Reed-Sternberg (RS) cell. c Mummified RS cell. d Numerous CD30+ RS cells. e Mononuclear RS cell with CD15 staining in a Golgi distribution. f Numerous EBER-1+ Reed-Sternberg cells

B-cell is reported with increased frequency relative to the other B-cell lymphomas [21, 22].

Hodgkin lymphoma in A-T and a review of the literature

When comparing Hodgkin lymphoma in patients with ataxia telangiectasia to patients in the general population, notable differences involve the following: age at presentation, extent of disease involvement, histologic subtype, response to therapy and survival. A pediatric Hodgkin lymphoma case-control study comparing $20 \mathrm{HL}$ cases $(50 \%$ A-T, $45 \%$ immunoglobulin defects) from the ICR to 100 cases of HL in children without known immunodeficiency 

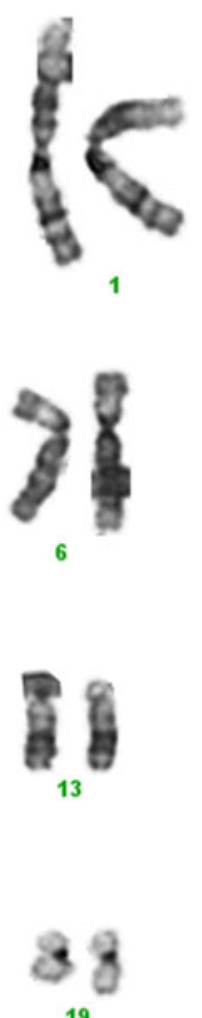

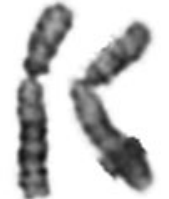

2

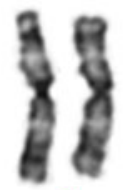

3
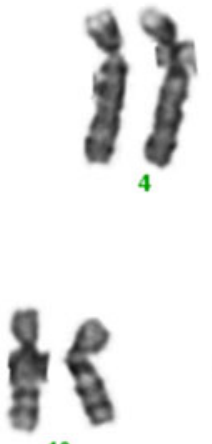

10
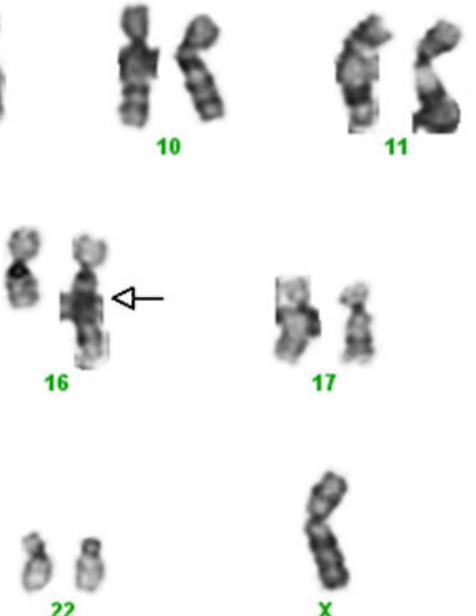

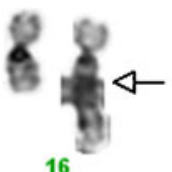

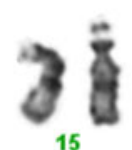

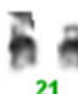

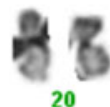

\section{$46, X Y, t(7 ; 7)(p 13 ; q 34), t(14 ; 16)(q 11.2 ; q 21)$}

Fig. 3 Cytogenetic analysis revealed 46,XY,t(7;7)(p13;q34),t(14;16)(q11.2;q21) characteristic of ataxia-telangiectasia

from the Late Effects Study Group confirmed that Hodgkin lymphoma occurs in A-T patients at a significantly younger age (mean 7.8 years) than in the general pediatric population (mean 11.5 years) [14]. In our literature review examining cases of HL in A-T (Table 1), the average age at diagnosis was 9.6 years old (range $3-25$, median 8.8 years). Often, diagnosed or suspected A-T patients present with recurrent sinopulmonary infections and are noted to have a lymphopenia which then leads to the diagnosis of malignancy. In some cases, as in our patient, the ataxia and telangiectasias may be subtle and the unusually young diagnosis of a particular malignancy leads to the search for a primary immunodeficiency.

All subtypes of HL have been reported in A-T; however, a review of the ICR shows that $42 \%$ of A-T patients show the mixed-cellularity subtype of HL and $33 \%$ of A-T patients have the lymphocyte depleted subtype [14]. These subtypes of HL are infrequently seen in developed countries, have an increased association with HIV, and are both highly associated with EBV [15]. Our patient's lymph node and bone marrow biopsies revealed nodular sclerosis $\mathrm{HL}$, which is seen most often in the general population [15], but is also the predominant subtype in another primary immunodeficiency, Wiskott-Aldrich syndrome [17]. Nodular sclerosis HL is less often associated with EBV, and is positive in only $10-40 \%$ of cases in the general population [15]. Table 1 shows a distribution of histologic subtypes similar to that of the ICR: $30 \%$ (11 of 37) lymphocyte depleted, $24 \%$ (nine of 37 ) mixed-cellularity, $13.5 \%$ (five of 37) nodular sclerosis, $30 \%$ (11 of 37) unspecified subtype, and one case which was classified as lymphocyte predominant HL.

A-T patients more often present with extranodal involvement and at an advanced stage [23]. In our review, $59 \%$ (16 of 27) cases were stage IV at diagnosis; and in instances where site of disease was specified, 50\% (13 of 26) cases reviewed showed mediastinal involvement across all subtypes (Table 1). In contrast, mediastinal involvement is uncommon among the mixed-cellularity and lymphocytedepleted subtypes seen in the general population of $\mathrm{HL}$ patients [15].

A-T patients with HL have significantly reduced survival compared to HL patients without immunodeficiency [24], but it is somewhat challenging to make an honest comparison of HL treatment related to survival between the two groups. This is mainly due to the fact that standardized cohorts and retrospective studies examining the outcomes of HL in the general population are difficult to compare to individual case reports and decade-spanning case reviews that include varying degrees of detail and 
Table 1 Summary of Hodgkin lymphoma in ataxia telangiectasia patients reported in the literature

\begin{tabular}{|c|c|c|c|c|c|}
\hline Author/year & Age/sex & Subtype/stage & Involved sites & Presenting symptoms & $\begin{array}{l}\text { Prior A-T } \\
\text { diagnosis? }\end{array}$ \\
\hline $\begin{array}{l}\text { Boder [16] } \\
\text { Dugois [31] }\end{array}$ & $\begin{array}{l}\mathrm{n} / \mathrm{a} \\
12 / \mathrm{M}\end{array}$ & $\begin{array}{l}\mathrm{HD} \\
\mathrm{HD} / \mathrm{IVB}\end{array}$ & Axillary node/pharynx & Lymphopenia & $\mathrm{N}$ \\
\hline Morgan [32] & $9 / \mathrm{M}$ & $\mathrm{LP} / \mathrm{IV}$ & Mediastinum & & \\
\hline $\begin{array}{l}\text { Harris [33] } \\
\text { Frizzera [34] }\end{array}$ & $\begin{array}{l}4 / \mathrm{M} \\
\text { All }<10 \text { years }\end{array}$ & $\begin{array}{l}\mathrm{MC} \\
\mathrm{MC} \\
\mathrm{LD} \times 3 \text { cases }\end{array}$ & Cervical node & & $\mathrm{Y}$ \\
\hline Bernstein [35] & $25 / \mathrm{F}$ & $\mathrm{MC} / \mathrm{IIIB}$ & Cervical node & & $\mathrm{Y}$ \\
\hline Pritchard [36] & $31 / 2$ & ${ }^{\mathrm{a}} \mathrm{LP} / \mathrm{IA}$ & Cervical node & Lymphadenopathy/ataxia & $\mathrm{N}$ \\
\hline Weyl Ben Arush [37] & $5 / \mathrm{F}$ & NS/III & Mediastinal nodes & Ataxia and pneumonia & $\mathrm{N}$ \\
\hline \multirow[t]{6}{*}{ Sandoval $[25,38]$} & $\begin{array}{l}15.6 / \mathrm{F} \\
5.7 / \mathrm{M} \\
12.3\end{array}$ & $\begin{array}{l}\text { 9/F } \\
\text { NS/IVB } \\
\text { NS/IVB } \\
\text { LD/IV }\end{array}$ & $\begin{array}{l}\text { HD/II } \\
\text { Soft tissue densities } \\
\text { Bilateral infiltrates } \\
\text { Lymphadenopathy }\end{array}$ & $\begin{array}{l}\text { mediastinum } \\
\text { Fever and cough } \\
\text { Fever and cough }\end{array}$ & $\mathrm{Y}$ \\
\hline & $\begin{array}{l}20.5 / \mathrm{M} \\
17.9 / \mathrm{F}\end{array}$ & $\begin{array}{l}\text { LD/IVB } \\
\text { HD/II OR IIIB }\end{array}$ & Medistinal/hilar nodes & Fever weight loss & \\
\hline & $11.7 / \mathrm{F}$ & $\mathrm{HD} / \mathrm{IVB}$ & & & \\
\hline & $12.1 / \mathrm{F}$ & HD & & & \\
\hline & $15.2 / \mathrm{M}$ & NS/IVB & Mediastinal mass & & \\
\hline & $\begin{array}{l}3.9 / \mathrm{M} \\
11.9 / \mathrm{M}\end{array}$ & $\begin{array}{l}\mathrm{MC} / \mathrm{IV} \\
\mathrm{MC} / \mathrm{IVB}\end{array}$ & Mediastinal node & & \\
\hline \multirow[t]{2}{*}{ Murphy [23] } & $3 / \mathrm{F}$ & HD & Pharynx & & \\
\hline & $11 / \mathrm{F}$ & $\mathrm{HD} / \mathrm{IV}$ & $\begin{array}{l}\text { Stomach, small bowel, } \\
\text { and liver, marrow }\end{array}$ & $\begin{array}{l}\text { weakness, lymphopenia, } \\
\text { and pleural effusions }\end{array}$ & $\mathrm{N}$ \\
\hline \multirow[t]{2}{*}{ Irsfeld [39] } & $8.8 / \mathrm{F}$ & MC/IIA & Cervical node, mediastinum & Numerous infections & $\mathrm{Y}$ \\
\hline & $5.8 / \mathrm{F}$ & $\mathrm{MC} / \mathrm{IVB}$ & Hilar/mediastinal masses & CMV pneumonia & $\mathrm{Y}$ \\
\hline \multirow[t]{5}{*}{ Yalcin [40] } & $8 / \mathrm{F}$ & $\mathrm{HD} / \mathrm{IIE}$ & Lung, mediastinal, hilar nodes & Cough, fever, sweating & $\mathrm{Y}$ \\
\hline & $8 / \mathrm{F}$ & $\mathrm{MC} / \mathrm{IIE}$ & Lung, mediastinal, hilar nodes & Cough, fever, sweating & $\mathrm{Y}$ \\
\hline & $\begin{array}{l}8 / \mathrm{F} \\
8 / \mathrm{F}\end{array}$ & $\begin{array}{l}\mathrm{LD} / \mathrm{IV} \\
\mathrm{LD} / \mathrm{IIB}\end{array}$ & $\begin{array}{l}\text { Mediastinal mass/nodes } \\
\text { Supraclavicular/hilar nodes }\end{array}$ & Cough, fever, sweating & $\mathrm{N}$ \\
\hline & $8 / \mathrm{F}$ & LD/IIA & Cervical nodes & & \\
\hline & $\begin{array}{l}6.5 / \mathrm{F} \\
9 / \mathrm{F}\end{array}$ & $\begin{array}{l}\text { LD/IV } \\
\text { NS/IIA }\end{array}$ & Lungs, mediastinum & & \\
\hline $\begin{array}{l}\text { Sandoval [42] } \\
\text { Etzioni [43] } \\
\text { Moin [44] }\end{array}$ & $\begin{array}{l}8 / \mathrm{F} \\
3 / \mathrm{F} \\
\mathrm{n} / \mathrm{a}\end{array}$ & $\begin{array}{l}\text { LD/IVB } \\
\text { HD } \\
\text { HD }\end{array}$ & $\begin{array}{l}\text { Mediastinal node } \\
\text { Thoracic mass }\end{array}$ & $\begin{array}{l}\text { Pneumonitis (CMV) } \\
\text { Hyper IgM syndrome }\end{array}$ & $\mathrm{N}$ \\
\hline Kaymaz [45] & $9 / \mathrm{M}$ & $\mathrm{MC} / \mathrm{IV}$ & Paratracheal/hilar nodes, lung nodules & Pneumonia & Y \\
\hline
\end{tabular}

$H D$ Hodgkin disease, $L P$ lymphocyte predominant, $M C$ mixed cellularity, $L D$ lymphocyte depleted, $N S$ nodular sclerosis

${ }^{\text {a }}$ The biopsy also contained areas of LD

follow-up. Although some A-T patients have received standard and reduced radiation, none reported in the literature have received the standard dose chemotherapy for HL based on established clinical trials [25], yet there is no clear evidence that reduced-dose chemotherapy is more appropriate for A-T [25].

The role of EBV in malignancy and A-T

In 1981, an EBV genome-positive lymphoma was found in a mesenteric lymph node of a 9 year-old A-T patient [26].
However, the role of EBV in A-T-associated lymphomas is unclear. One of the mechanisms that may be involved in EBV-associated lymphomas is the loss of immune surveillance, which can result in a derangement of the cytotoxic T-lymphocytes important in limiting the proliferation of $\mathrm{EBV}+$ cells. In the late 1970s, several studies of EBV in A-T patients reported an increased incidence of high antibody titers to VCA and EA. In conjunction with these findings, low to undetectable antibody titers to EBNA were noted, suggesting a deficiency of EBV-CTL activity $[27,28]$. This pattern of high titers to VCA and 
EA with low to undetectable titers of EBNA is nonspecific and has been observed in autoimmune disease, EBVassociated malignancy and other types of immune dysfunction [29]. A study examining EBV titers in 60 A-T patients aged 3.5-20 years found that six of the patients went on to develop a hematolymphoid malignancy, and one of these six patients developed HL. The age at diagnosis, stage, histologic subtype and outcome were not reported, and the HL biopsy was not tested for the EBV genome [30]. EBV serology is not a dependable marker for malignancy in immunocompromised patients, and subsequent case reports on A-T patients with Hodgkin lymphoma have not examined tissue biopsies for the Epstein-Barr virus. To the best of our knowledge, this is the first known case of EBER-1 positive Hodgkin lymphoma in an ataxia-telangiectasia patient.

\section{Conclusion}

Notable features of this case included the unusually young age at presentation, advanced stage with bone marrow involvement at diagnosis and EBER positivity. Although the patient had a history of frequent sinopulmonary infections, a primary immunodeficiency was not diagnosed until the histologic diagnosis of Hodgkin lymphoma was made on the bone marrow and mediastinal lymph node. The elevated alpha-fetoprotein, decreased $\operatorname{IgG} 2$ and $\operatorname{IgA}$, and most importantly, the confirmatory chromosomal breakage with $7 ; 7$ and $14 ; 14$ translocations further supported the diagnosis of ataxia-telangiectasia. This case highlights the importance of evaluating young children with advanced stage Hodgkin lymphoma for the presence of primary immunodeficiency.

Conflict of interest The authors declare that they have no conflict of interest.

\section{References}

1. Savitsky K, Bar-Shira A, Gilad S (1995) A single ataxia telangiectasia gene with a product similar to PI-3 kinase. Science 268:1749-1753

2. Gatti RA, Berkel I, Boder E et al (1988) Localization of an ataxiatelangiectasia gene to chromosome 11q22-23. Nature 336:577580

3. Lim MS, Elenitoba-Johnson KS (2004) The molecular pathology of primary immunodeficiencies. J Mol Diagn 6:59-83

4. Woods CG, Bundey SE, Taylor AM (1990) Unusual features in the inheritance of ataxia telangiectasia. Hum Genet 84:555562

5. Swift M, Morrell D, Cromartie E, Chamberlin AR, Skolnick MH, Bishop DT (1986) The incidence and gene frequency of ataxiatelangiectasia in the United States. Am J Hum Genet 39:573-583
6. Morrell D, Cromartie E, Swift M (1986) Mortality and cancer incidence in 263 patients with ataxia-telangiectasia. J Natl Cancer Inst 77:89-92

7. Boder E, Sedgwick RP (1958) Ataxia-telangiectasia; a familial syndrome of progressive cerebellar ataxia, oculocutaneous telangiectasia and frequent pulmonary infection. Pediatrics 21:526-554

8. Sedgwick RP, Boder E (1960) Progressive ataxia in childhood with particular reference to ataxia-telangiectasia. Neurology 10:705-715

9. Boder E (1975) Ataxia-telangiectasia: some historic, clinical and pathologic observations. Birth Defects Orig Artic Ser 11:255-270

10. Nowak-Wegrzyn A, Crawford TO, Winkelstein JA (2004) Immunodeficiency and infections in ataxia-telangiectasia. J Pediatr 144:505-511

11. Taylor AM, Metcalfe JA, Thick J, Mak YF (1996) Leukemia and lymphoma in ataxia telangiectasia. Blood 87:423-438

12. Taylor AM, Harnden DG, Arlett CF, Harcourt SA, Lehmann AR, Stevens S et al (1975) Ataxia telangiectasia: a human mutation with abnormal radiation sensitivity. Nature 258:427-429

13. Filipovich AH, Mathur A, Kamat D (1992) Primary immunodeficiencies: genetic risk factors for lymphoma. Cancer Res $52: 5465 \mathrm{~s}-5467 \mathrm{~s}$

14. Robison LL, Stoker V, Frizzera G et al (1987) Hodgkin's disease in pediatric patients with naturally occurring immunodeficiency. Am J Pediatr Hematol Oncol 9:189-192

15. Swerdlow S, Campo E, Harris N, Jaffe E, Pileri S, Stein H, et al. (eds) (2008) WHO Classification of Tumors of Haematopoietic and Lymphoid Tissues, 4th edn. Lyon 2008. International Agency for Research on Cancer (IARC)

16. Kersey JH, Spector BD, Good RA (1973) Primary immunodeficiency diseases and cancer: the immunodeficiency-cancer registry. Int J Cancer 12:333-347

17. Mueller BU, Pizzo PA (1995) Cancer in children with primary or secondary immunodeficiencies. J Pediatr 126:1-10

18. Toledano SR, Lange BJ (1980) Ataxia-telangiectasia and acute lymphoblastic leukemia. Cancer 45:1675-1678

19. Viniou N, Terpos E, Rombos J, Vaiopoulos G, Nodaros K, Stamatopoulos K et al (2001) Acute myeloid leukemia in a patient with ataxia-telangiectasia: a case report and review of the literature. Leukemia 15:1668-1670

20. Taylor AM (1992) Ataxia telangiectasia genes and predisposition to leukaemia, lymphoma and breast cancer. Br J Cancer 66:5-9

21. Makis A, Polychronopoulou S, Haidas S (2004) Osteosarcoma as a second tumor after treatment for primary non-Hodgkin's lymphoma in a child with ataxia-telangiectasia: presentation of a case and review of possible pathogenetic mechanisms. J Pediatr Hematol Oncol 26:444-446

22. Seidemann K, Henze G, Beck JD, Sauerbrey A, Kuhl J, Mann G et al (2000) Non-Hodgkin's lymphoma in pediatric patients with chromosomal breakage syndromes (AT and NBS): experience from the BFM trials. Ann Oncol 11(Suppl 1):141-145

23. Murphy RC, Berdon WE, Ruzal-Shapiro C et al (1999) Malignancies in pediatric patients with ataxia telangiectasia. Pediatr Radiol 29:225-230

24. Niehues T, Schellong G, Dorffel W, Bucsky P, Mann G, Korholz $\mathrm{D}$ et al (2003) Immunodeficiency and Hodgkin's disease: treatment and outcome in the DAL HD78-90 and GPOH HD95 studies. Klin Pädiatr 215:315-320

25. Sandoval C, Swift M (2003) Hodgkin disease in ataxiatelangiectasia patients with poor outcomes. Med Pediatr Oncol $40: 162-166$

26. Saemundsen AK, Berkel AI, Henle W et al (1981) Epstein-Barr virus-carrying lymphoma in a patient with ataxia-telangiectasia. Br Med J (Clin Res Ed) 282:425-427 
27. Berkel AI, Henle W, Henle G et al (1979) Epstein-Barr virusrelated antibody patterns in ataxia-telangiectasia. Clin Exp Immunol 35:196-201

28. Joncas J, Lapointe N, Gervais F et al (1977) Unusual prevalence of Epstein-Barr virus early antigen (EBV-EA) antibodies in ataxia telangiectasia. J Immunol 119:1857-1859

29. Gulley ML (2001) Molecular diagnosis of Epstein-Barr virusrelated diseases. J Mol Diagn 3:1-10

30. Berkel AI, Henle W, Henle G et al (1985) Immune response to Epstein-Barr virus (EBV) in ataxia-telangiectasia: EBV-specific antibody patterns and their relation to cell-mediated immunity. Kroc Found Ser 19:287-300

31. Dugois P, Amblard P, Imbert R (1967) Ataxia telangiectasia and Hodgkin's disease (apropos of a case). Bull Soc Fr Dermatol Syphiligr 74:507-510

32. Morgan JL, Holcomb TM, Morrissey RW (1968) Radiation reaction in ataxia telangiectasia. Am J Dis Child 116:557-558

33. Harris VJ, Seeler RA (1973) Ataxia-telangiectasia and Hodgkin's disease. Cancer 32:1415-1420

34. Frizzera G, Rosai J, Dehner LP et al (1980) Lymphoreticular disorders in primary immunodeficiencies: new findings based on an up-to-date histologic classification of 35 cases. Cancer 46:692-699

35. Bernstein R, Pinto M, Jenkins T (1981) Ataxia telangiectasia with evolution of monosomy 14 and emergence of Hodgkin's disease. Cancer Genet Cytogenet 4:31-37

36. Pritchard J, Sandland MR, Breatnach FB, Pincott JR, Cox R, Husband P (1982) The effects of radiation therapy for Hodgkin's disease in a child with ataxia telangiectasia: a clinical, biological and pathologic study. Cancer 50:877-886

37. Weyl Ben Arush M, Rosenthal J, Dale J, Horovitch Y, Herzl G, Ben Arie J et al (1995) Ataxia telangiectasia and lymphoma: an indication for individualized chemotherapy dosing-report of treatment in a highly inbred Arab family. Pediat Hematol Oncol 12:163-169
38. Sandoval C, Swift M (1998) Treatment of lymphoid malignancies in patients with ataxia-telangiectasia [see comment]. Med Pediat Oncol 31:491-497

39. Irsfeld H, Korholz D, Janssen G et al (2000) Fatal outcome in two girls with Hodgkin disease complicating ataxiatelangiectasia (Louis-Barr syndrome) despite favorable response to modified-dose chemotherapy. Med Pediatr Oncol 34:62-64

40. Yalcin B, Kutluk MT, Sanal O, Akyuz C, Anadol D, Caglar M et al (2002) Hodgkin's disease and ataxia telangiectasia with pulmonary cavities. Pediatr Pulmonol 33:399-403

41. Tamminga RY, Dolsma WV, Leeuw JA, Kampinga HH (2002) Chemo- and radiosensitivity testing in a patient with ataxia telangiectasia and Hodgkin disease. Pediatr Hematol Oncol 19:163-171

42. Sandoval C, Swift M (2004) Cytomegalovirus pneumonitis in a patient with Hodgkin disease and ataxia-telangiectasia. Pediatr Pulmonol 37:559-560

43. Etzioni A, Ben-Barak A, Peron S et al (2007) Ataxiatelangiectasia in twins presenting as autosomal recessive hyperimmunoglobulin M syndrome. Isr Med Assoc J 9:406-407

44. Moin M, Aghamohammadi A, Kouhi A, Tavassoli S, Rezaei N, Ghaffari SR et al (2007) Ataxia-telangiectasia in Iran: clinical and laboratory features of 104 patients. Pediatr Neurol $37: 21-28$

45. Kaymaz NE, Kupeli S, Yalcin B (2009) Hemorrhagic cystitis in a child with Hodgkin lymphoma and ataxia-telangiectasia after cyclophosphamide. Pediatr Blood Cancer 53:516

46. Peterson RD, Kelly WD, Good RA (1964) Ataxia-telangiectasia. Its association with a defective thymus, immunological-deficiency disease, and malignancy. Lancet 283:1189-1193

47. Loeb DM, Lederman HM, Winkelstein JA (2000) Lymphoid malignancy as a presenting sign of ataxia-telangiectasia. J Pediatr Hematol/Oncol 22:464-467 